NEWS AND NOTES

With the forthcoming March 1964 number, Leo B. Lott, of the Ohio State University, becomes the News and Notes Editor.

\title{
NOMINATIONS
}

The Association's Committee on Nominations invites all members to propose candidates for the elective offices of the Association, to wit: President Elect, three Vice Presidents, Secretary, Treasurer, and eight members for two-year terms on the Council. Suggestions and supporting statements may be sent to any member of the Committee: J. Austin Ranney, University of Wisconsin, Chairman; Rupert Emerson, Harvard University; Robert Scalapino, University of California (Berkeley); Avery Leiserson, Vanderbilt University; James Prothro, University of North Carolina; Ruth G. Weintraub, Hunter College. The sooner suggestions are received the better; to be considered at all they must arrive by March 15 , 1964.

\section{PROGRAM: 1964 ANNUAL MEETING}

As stated in an earlier letter to department chairmen, the Program Committee for the 1964 annual meeting (Chicago, 9-12 September) invites newer members of the Association to submit papers for consideration by the appropriate section chairmen listed below. This procedure replaces last year's separately organized selected-paper panels but is designed to afford the same opportunity. To be considered, papers should be submitted no later than 15 March 1964. Committee members: Chairman, Leon D. Epstein, University of Wisconsin; National Government and Politics-Richard M. Scammon, Director, Bureau of the Census; Comparative Politics (Western)-John E. Turner, University of Minnesota; Comparative Politics (Developing Nations)- Leonard Binder, University of Chicago; State and Local Politics-Lawrence J. R. Herson, Ohio State University; Public Administration-Robert V. Presthus, Cornell University; Public Law and Judicial Process-Walter F. Murphy, Princeton University; International Relations and Foreign PolicyBernard Cohen, University of Wisconsin (replacing Stanley Hoffmann); New Research Techniques-John Wahlke, State University of New York at Buffalo; Political Theory-John D. Lewis, Oberlin College; and for the Conference on Soviet and Communist Studies-Robert Tucker, Princeton University. 


\section{WASHINGTON OFFICE NEWSLETTER}

Our 59th Annual Meeting, held in New York City from September 4-7, was in many important respects the most extensive in the Association's history. About 3,000 persons-a record attendance total-were registered in the Commodore and Biltmore Hotels. Scheduled during the week were 68 panel meetings, during which 124 research papers were presented for discussion. Among other highlights was presentation of the following awards:

Leonard D. White Award, to Kart A. Hochschwender, of Yale University, for his dissertation entitled, "The Politics of Civil Service Reform in West Germany."

The Woodrow Wilson Foundation Award, to INIS L. ClaUde, JR., professor of political science at the University of Michigan, for his book, Power and International Relations.

Congressional Distinguished Service Awnrds, to Senators Clinton P. Anderson (D-N.M.), Leverett Saltonstall (R-Mass.), and Representatives George Mahon (D-Tex.) and Thomas B. Curtis (R-Mo.).

Two New Awards Announced. The Association has established two new awards for research, to be presented in conjunction with the Annual Meeting. They are:

The Edward S. Corwin Award for the best doctoral dissertation in the field of public law, broadly defined to include the judicial process, judicial biography, judicial behavior, the American Constitutional system, or any other substantive area which deals in a significant fashion with a topic related to or having a substantial impact on the American Constitution. The dissertation must have been completed and accepted before the end of this (1963) calendar year. Entries are to be submitted through departmental chairmen, and departments are requested to submit to the Association's Washington office not more than one dissertation each for consideration for the award. Entries should be submitted not later than April 15, 1964.

The Pr Sigma Alpha Award for the best paper presented during the Association's Annual Meeting. This award, established in cooperation with the political science honorary fraternity, will be presented for the first time at the Annual Meeting in 1964 (for the best paper presented at the 1963 meeting) and will carry with it an honorarium of $\$ 250$.

Following are the deadlines for submission of manuscripts and suggestions for other awards to be presented at the Association's 1964 Annual Meeting, September 9-12, Pick-Congress Hotel, Chicago, Illinois.

\section{Leonard $D$. White Memorial Award}

This award is for the best doctoral dissertation within the general field of public administration, including broadly related problems of policy formation and administrative history. The dissertation must have been completed and accepted before the end of this calendar year, 1963. Departments are requested to submit to the Association office not more than one dissertation each for consideration for the award, which carries with it an honorarium of $\$ 250$. Dissertations should be submitted as soon as possible and not later than April 15, 1964.

\section{Atherton Press Prize}

This prize was not awarded in 1963 , becausein the judgment of the committee-none of the manuscripts submitted clearly met the criteria established in cooperation with Atberton Press. The competition will be continued, however, for the best original manuscript in the field of political science. Manuscripts entered for consideration for the $\$ 1000$ prize in 1964 must be mailed to the Association office prior to March 1, 1964. They are to be no longer than 200,000 words, and Atherton Press will have first option on publication of manuscripts submitted for the prize. As in the past, the Association reserves the right to withhold the prize, if in the opinion of the committee, no sufficiently meritorious manuscript is submitted.

\section{Woodrow Wilson Foundation Award}

The Association would be pleased to receive recommendations for this award, for the best book published in 1963 on government, politics or international affairs. Suggestions should be conveyed to the national office prior to February 1,1964 .

Annual Meeting Organization. Leon Epstein, chairman of the Program Committee, is inviting advanced graduate students as well as newer members of the Association to submit papers for consideration by the appropriate section chairmen for the 1964 Annual Meeting. Papers should be submitted as early as possible, and in any event no later than March 15, 1964, to the following: 
National Government and Politics-Richard M. Scammon, Director, Bureau of the Census Comparative Politics (Western)-John E. Turner, University of Minnesota

Comparative Politics (Developing Nations)Leonard Binder, University of Chicago

State and Local Politics-Lawrence J. R. Herson, Ohio State University

Public Administration-Robert V. Presthus, Cornell University

Public Law and Judicial Process-Walter F. Murphy, Princeton University

International Relations and Foreign PolicyBernard Cohen, University of Wisconsin (replacing Stanley Hoffman)

New Research Techniques-John Wahlke, State University of New York at Buffalo

Political Theory-John D. Lewis, Oberlin College

\section{PROFESSIONAL CONFERENCES}

\section{Fifty-ninth Annual Meeting of the American Political Science Association}

\section{Minutes of the Council Meeting}

The Council of the American Political Science Association met at 9:30 A.M., September 3, 1963, in the Club Suite of the Commodore Hotel in New York City, with President Carl J. Friedrich presiding. The following members of the Council, nominees for election in 1963, and former presidents of the Association were present: William Anderson, Stephen K. Bailey, Franklin L. Burdette, Byrum E. Carter, Gwendolen M. Carter, Frederic N. Cleaveland, Karl W. Deutsch, Leon D. Epstein, Morton Grodzins, Charles B. Hagan, John H. Hallowell, H. Field Haviland, Jr,, E. Pendleton Herring, Lawrence J. R. Herson, Max M. Kampelman, Evron M. Kirkpatrick, Ruth C. Lawson, John D. Lewis, Harvey C. Mansfield, Robert G. McCloskey, J. Roland Pennock, Ithiel de Sola Pool, C. Herman Pritchett, Emmette S. Redford, Leo C. Riethmayer, Wallace S. Sayre, Harold Sprout, David B. Truman, Vernon Van Dyke, Sheldon S. Wolin, and Bryce Wood.

Prior to the meeting the Executive Director had mailed to each Council member an agenda book which included the reports of the Executive Director, the Editor of the REviEw, the Treasurer, Auditor, and the Co-Chairman of the Joint Committee on Political Science and Administrative Law, as well as the minutes of Executive Committee meetings during the past year. These reports were the basis of Council discussion and are available to Association members. The report of the 1963 Program Committee Chairman is now in process of coming to life.

\section{Conference on Soviet and Communist Studies-} Robert Tucker, Princeton University

International Political Science Association. An Executive Committee meeting and Round Table of IPSA was held at Nuffield College, Oxford, September 18-24, 1963. The topics for discussion at the Round Table were Federalism and Decentralization. Over thirty participants from twelve countries took part in the Round Table. Professor Carl Friedrich, Harvard University, was in charge of the sessions on Federalism and Professor A. H. Hanson, University of Leeds, was in charge of the sessions on Decentralization.

The next International Congress of IPSA will be held in Geneva, Switzerland, September 21-26, 1964. Social Science Research Council will make some travel grants for Americans participating in the program at the IPSA Geneva Congress; the deadline for applications is April 1, 1964.

The Editor of the Review requested and received unanimous approval of the appointment of Robert E. Lane of Yale and Stanley Hoffmann of Harvard to replace Dwight Waldo and Samuel H. Beer on the Review Editorial Board. The Editor also mentioned that, although manuscripts are received in considerable number, there is no surplus of good manuscripts for inclusion in the REview.

In amplifying his report the Executive Director announced that the fifty-ninth Annual Meeting is expected to be the largest in the history of the Association with approximately three thousand in attendance. This year there are nearly as many persons participating in the program as were in attendance at the 1953 Annual Meeting. Association membership continues to grow, averaging an increase of over one hundred per month during the past year.

Among other significant developments of this year is the greater recognition accorded political science through its inclusion in the Division of Behavioral Sciences of the National Academy of Sciences, National Research Council.

Significant new programs of the Association include the Congressional Staff Fellowship Program, supported by a grant from the Ford Foundation, under which four appointments from Senate and House offices have been made for the coming year. It is expected that a larger number of appointments will be made in subsequent years. The Seminar for Freshman Congressmen, organized to give new Congressmen an insight into Congressional operations and conducted for the first time in January, 1963, found over 50 of the 67 new members of the House in at- 